\title{
ANALISIS KESULITAN MEMBACA PERMULAAN SISWA KELAS 1 SEKOLAH DASAR
}

\author{
Mitra Rahma ${ }^{1}$, Febrina Dafit ${ }^{1}$ \\ ${ }^{1}$ Universitas Islam Riau, Riau \\ *Corresponding Address: mitrarahma@student.uir.ac.id
}

Naskah diterima: 3 Agustus 2021| Disetujui: 29 Agustus 2021 | Diterbitkan: 30 Agustus 2021

\begin{abstract}
This study aims to explain the difficulty of reading at the beginning of grade 1 at SDN 022 Pulau Baru Kopah. This type of research is descriptive qualitative research. The subjects of this study were class 1A teachers and class 1A students. Data collection techniques used are interviews, observation and documentation. The data analysis technique uses the Milles and Huberman model with stages, data reduction, data presentation, and drawing conclusions. The results showed that $47.6 \%$ of students who had difficulty reading the beginning were, (1) students did not recognize letters, (2) could not read syllables, (3) could not read word for word, (4) could not read diphthongs, clusters and diagraphs, (5) cannot read consonants, (6) cannot read vowels, (7) series, (8) wrong prephasers, (9) do not know the meaning of words. The solution given by the teacher to overcome the difficulty of early reading is to provide additional hours, pay more attention to students who have difficulty reading the beginning and teach students to recognize letters with creative techniques such as singing, students are asked to write sentences and aloud and so on.
\end{abstract}

Keywords: Difficulty, Beginning reading , Student, SD

Abstrak: Penelitian ini bertujuan untuk mendeskripsikan kesulitan membaca permulaan siswa kelas 1 di SDN 022 Pulau Baru Kopah. Jenis penelitian ini adalah penelitian kualitatif deskriptif. Subjek dalam penelitian ini adalah guru kelas 1A dan siswa kelas 1A. Teknik pengumpulan data yang digunakan adalah wawancara, observasi, dan dokumentasi. Teknik analisis data menggunakan model Milles and Huberman dengan tahapan reduksi data, penyajian data, dan penarikan kesimpulan. Hasil penelitian menunjukkan bahwa $47,6 \%$ siswa yang mengalami kesulitan-kesulitan membaca permulaan yaitu, (1) siswa belum mengenal huruf, (2) belum bisa membaca suku kata, (3) belum bisa membaca kata demi kata, (4) belum bisa membaca huruf diftong, kluster, dan diagraf, (5) belum bisa membaca huruf konsonan, (6) belum mampu membaca huruf vokal, (7) pengulangan, (8) pemprafase yang salah, (9) belum mengenal makna kata. Solusi yang diberikan guru untuk mengatasi kesulitan membaca permulaan adalah memberikan jam tambahan, memberikan perhatian lebih kepada siswa yang memiliki kesulitan membaca permulaan, dan mengajari siswa mengenal huruf dengan teknik yang kreatif seperti huruf dijadikan nyanyian, siswa diminta menulis kalimat, dan membacanya dengan keras dan sebagainya.

Kata kunci : Kesulitan, Membaca Permulaan, Siswa, SD 


\section{PENDAHULUAN}

Kesulitan belajar merupakan persoalan umum dan lumrah yang terjadi pada siswa dalam akademisnya. Namun, masalah kesulitan belajar pada siswa tidak boleh dipandang remeh. Masalah tersebut hendaknya segera mungkin dilakukan tindakan atau penanganan khusus, agar siswa mampu menyelesaikan studinya di sekolah (Masykuri, 2017).

Pembelajaran di sekolah dasar nampaknya belum berhasil mengatasi kesulitan belajar yang dialami oleh siswa, khususnya untuk permasalahan kesulitan membaca pada siswa seringkali kurang dapat perhatian dari guru. Membaca merupakan suatu proses yang tidak hanya mengucapkan tulisan saja, akan tetapi juga melibatkan berbagai aktivitas visual, berpikir, psikolinguistik, dan metakognitif (Rafika \& Lestari, 2020).

Pembelajaran membaca di sekolah dasar terdiri dari dua bagian, yakni membaca permulaan dan membaca lanjut. Membaca permulaan berada di kelas 1 dan 2, membaca lanjut mulai dari kelas 3 dan seterusnya. Membaca permulaan mempunyai kedudukan yang sangat penting. Keterampilan membaca permulaan akan sangat berpengaruh terhadap keterampilan membaca selanjutnya. Sebagai keterampilan yang mendasari keterampilan berikutnya, membaca benar-benar memerlukan perhatian guru. Jika dasar itu tidak kuat, maka pada tahap membaca permulaan siswa akan mengalami kesulitan untuk dapat memiliki keterampilan membaca yang memadai (Muhyidin et al, 2018).

Mabunga mengemukakan bahwa melalui membaca permulaan, sesungguhnya proses kognitif siswa sedang berlangsung untuk dapat mengetahui setiap makna yang tertulis di dalamnya. Membaca permulaan dilakukan melalui pengenalan bahasa tulis, mengenal huruf, serta mengeja secara sederhana. Pada kegiatan tersebut, siswa melakukan kegiatan menyuarakan lambang-lambang bunyi bahasa (Mabunga et al, 2019).

Tahap awal membaca permulaan pada siswa dikenalkan dengan bentuk huruf abjad dari A/a sampai Z/z. Huruf-huruf tersebut perlu dilafalkan sesuai dengan bunyinya. Setelah siswa diperkenalkan dengan bentuk huruf abjad dan melafalkannya, langkah selanjutnya siswa diperkenalkan dengan mengeja suku kata, membaca kata, dan membaca kalimat pendek (Pratiwi \& Ariawan, 2017).

Berdasarkan hasil studi pendahuluan awal peneliti di SDN 002 Pulau Baru Kopah Kec. Kuantan Tengah Kab. Kuantan Singingi, pada proses pembelajaran di kelas 1 peneliti memperoleh informasi bahwa masih banyak siswa yang memiliki kesulitan dalam membaca permulaan. Permasalahan yang dialami siswa beragam. Contohnya, siswa yang belum bisa mengenal dan membedakan huruf yang bunyinya hampir sama seperti huruf $b$ dan $d$, huruf $p$ dan $q$, huruf $f$ dan $v$, huruf $m$ dan $w$, serta saat 
sedang membaca apa yang diucapakan siswa tidak sesuai dengan rangkaian huruf yang dibacanya, saat mengeja ada siswa yang menghilangkan huruf dan saat membaca masih terbata-bata.

Berdasarkan permasalahan di atas maka peneliti tertarik untuk melakukan sebuah penelitian. Rumusan masalah pada penelitian ini adalah (1) Bagaimana kesulitan-kesulitan membaca permulaan siswa kelas 1 SDN 002 Pulau Baru Kopah?, (2) Bagaimana solusi yang diberikan guru untuk mengatasi kesulitan membaca permulaan siswa kelas 1 SDN 002 Pulau Baru Kopah. Sedangkan tujuan dari dilakukannya penelitian ini adalah (1) Mengetahui kesulitan-kesulitan membaca permulaan siswa kelas 1 SDN 002 Pulau Baru Kopah, (2) Mengetahui solusi yang diberikan guru untuk mengatasi kesulitan membaca permulaan siswa kelas 1 SDN 002 Pulau Baru Kopah.

\section{METODE}

Penelitian ini dilaksanakan di SDN 022 Pulau Baru Kopah. SDN 022 Pulau Baru Kopah adalah salah satu sekolah dasar yang berada di wilayah Kecamatan Kuantan Tengah, Kabupaten Kuantan Singingi Provinsi Riau. Penelitian ini dilakukan di kelas IA SDN 002 Pulau Baru Kopah dari tanggal 13 Juli 2021 sampai dengan 03 Agustus 2021.

Penelitian ini menggunakan jenis penelitian deskriptif kualitatif karena peneliti ingin mendeskripsikan suatu fenomena sesuai dengan keadaan yang sebenarnya dialami oleh subjek penelitian, dalam penelitian ini peneliti ingin mendeskripsikan kendala guru dalam menerapkan penilaian autentik (Dafit \& Ramadan, 2020). Data didapatkan dari hasil observasi, wawancara, dan dokumentasi. Peneliti melakukan wawancara dengan guru kelas 1A dan siswa kelas 1 di SDN 002 Pulau Baru Kopah mengenai kesulitan membaca permulaan siswa. Peneliti melakukan wawancara dengan guru dan siswa kelas 1 sampai peneliti mendapatkan data yang peneliti butuhkan. Serta, peneliti melakukan observasi (pengamatan) selama proses pembelajaran berlangsung. Pada saat peneliti melaksanakan kegiatan observasi, yang menjadi fokus peneliti adalah kesulitan membaca permulaan siswa. Peneliti juga melakukan telaah terkait dokumen-dokumen yang menunjang datadata yang peneliti butuhkan seperti, buku catatan siswa, buku latihan siswa serta dokumen-dokumen lainnya. Setelah peneliti mendapatkan data, kemudian dilakukan analisis data menggunakan model Milles and Huberman dengan tahapan reduksi data, penyajian data, dan penarikan kesimpulan. Data yang didapatkan mengenai kesulitan membaca permulaan siswa kelas 1 di SDN 002 Pulau Baru Kopah. Berikut kisi-kisi instrumen penelitian yang peneliti gunakan untuk mengumpulkan data di lapangan. 
Tabel 1. Kisi-kisi Pedoman Wawancara Kesulitan Membaca Permulaan

\begin{tabular}{|c|l|ll|}
\hline No & \multicolumn{1}{|c|}{ Indikator } & \multicolumn{2}{|c|}{ Sub Indikator } \\
\hline 1. & Mengenal Huruf & 1. & Mengidentifikasi huruf vokal \\
& & 2. & Mengidentifikasi huruf konsonal \\
& & 3. & Mengidentifikasi huruf Diftong (ai, au, ei, oi) \\
\hline 2. & Membaca Kata & 1. & Mengidentifikasi Huruf \\
& & 2. & Merangkai Susunan Kata \\
& & 3. & Mengidentifikasi Kata \\
\hline 3. & Membaca Kata yang tidak & 1. & Mengidentifikasi Huruf \\
& mempunya arti & 2. & Merangkai Susunan Kata \\
\hline 4. & Kelancaran Membaca & 3. & Mengidentifikasi Kata \\
& Nyaring dan Pemahaman & 2. & Mengidentifikasi Huruf \\
& Membaca & 3. & Penggunaan Tanda Baca \\
& & 4. & Kelancaran Membaca \\
& 5. & Kemampuan menjawab soal tentang isi bacaan \\
\hline
\end{tabular}

Sumber : Menurut Masykuri (2019)

Tabel 2. Kisi-kisi Pedoman Wawancara mengenai Solusi yang diberikan Guru

\begin{tabular}{|c|c|c|}
\hline No & Indikator & Sub Indikator \\
\hline 1. & $\begin{array}{l}\text { Menggunakan media } \\
\text { Pembelajaran }\end{array}$ & $\begin{array}{l}\text { 1. Media pembelajaran yang menarik dan efektif } \\
\text { 2. Menggunakan media gambar } \\
\text { 3. Menggunakan metode pembelajaran }\end{array}$ \\
\hline 2. & $\begin{array}{l}\text { Meningkatkan Rasa } \\
\text { Percaya diri dan Motivasi } \\
\text { Siswa }\end{array}$ & $\begin{array}{l}\text { 1. Menimbulkan rasa percaya diri siswa } \\
\text { 2. Memberikan motivasi siswa }\end{array}$ \\
\hline 3. & $\begin{array}{l}\text { Memberikan program } \\
\text { khusus membaca } \\
\text { remedial }\end{array}$ & Pemberian remedial kepada siswa yang mengalami kesulitan membaca \\
\hline
\end{tabular}

Sumber : Menurut Masykuri (2019)

\section{HASIL DAN PEMBAHASAN}

Berdasarkan hasil wawancara dan observasi yang dilakukan terhadap guru kelas 1 dan siswa kelas I SDN 022 Pulau Baru Kopah, dari 21 siswa terdapat 10 siswa yang mengalami kesulitan membaca permulaan. Persentase siswa yang mengalami kesulitan-kesulitan membaca permulaan yaitu $\frac{10}{21} \times 100=47,6 \%$. Berikut data-data dari 10 siswa kelas 1 yang mengalami kesulitan membaca permulaan. 
Tabel 3. Data Kesulitan Membaca Permulaan

\begin{tabular}{|c|c|c|}
\hline No & Nama Siswa & Data Kesulitan Membaca Permulaan Siswa \\
\hline 1. & Fauzan Irhab Nabil Siregar & $\begin{array}{l}\text { Fauzan Irhab Nabil Siregar berumur } 6 \text { tahun, berjenis kelamin laki- } \\
\text { laki dan pernah bersekolah di Taman Kanak-Kanak (TK). Fauzan } \\
\text { Irhab Nabil Siregar sudah mampu mengenal huruf A-Z. Kesulitan } \\
\text { yang dialami Fauzan Irhab Nabil Siregar dalam membaca permulaan } \\
\text { yaitu belum mampu membaca suku kata, belum mampu membaca } \\
\text { kata, belum mampu membaca huruf diftong, belum mampu } \\
\text { membaca huruf konsonan, vokal rangkap dan membaca kata yang } \\
\text { tidak mempunyai arti. Wawancara yang dilakukan terhadap Fauzan } \\
\text { Irhab Nabil Siregar menghasilkan deskripsi tentang faktor } \\
\text { penghambat dalam membaca yaitu, kurangnya minat belajar dan } \\
\text { kurangnya fasilitas belajar. Hal inilah yang menyebabkan mengalami } \\
\text { kesulitan membaca permulaan. Pembelajaran yang dilakukan Fauzan } \\
\text { Irhab Nabil Siregar di rumah yaitu, membaca huruf, membaca suku } \\
\text { kata, membaca kata yang dibacakan dan diajarkan oleh Ibunya. }\end{array}$ \\
\hline 2. & Muhammad Israfil & $\begin{array}{l}\text { Muhammad Israfil jenis kelamin laki-laki berumur } 7 \text { tahun dan } \\
\text { pernah bersekolah di Taman Kanak-Kanak (TK). Kesulitan yang } \\
\text { dihadapi Muhammad Israfil diantaranya, belum mampu mengenal } \\
\text { huruf A-Z ( masih susah melafalkan huruf, belum mampu membaca } \\
\text { suku kata, belum mampu membaca kata, belum mampu membaca } \\
\text { huruf diftong dan belum mampu membaca kata yang tidak } \\
\text { mempunyai arti. Wawancara yang dilakukan terhadap Muhammad } \\
\text { Israfil menghasilkan deskripsi tentang faktor penghambat dalam } \\
\text { membaca permulaan yaitu kurangnya minat belajar. Pembelajaran } \\
\text { yang dilakukan Muhammad Israfil di rumah yaitu, membaca huruf, } \\
\text { membaca suku kata, membaca kata yang dibacakan oleh Ibunya. }\end{array}$ \\
\hline 3. & Windri Sapitri & $\begin{array}{l}\text { Windri Sapitri berjenis kelamin perempuan, berumur } 7 \text { tahun. Windri } \\
\text { Sapitri pernah bersekolah di Taman Kanak-Kanak (TK). Sudah } \\
\text { mampu mengenal huruf A-Z. Kesulitan yang dialami Windri Sapitri } \\
\text { dalam membaca permulaan yaitu belum bisa membaca suku kata, } \\
\text { belum bisa membaca kata dan belum bisa membaca kata yang tidak } \\
\text { mempunyai arti. Wawancara yang dilakukan terhadap Windri Sapitri } \\
\text { menghasilkan deskripsi tentang faktor penghambat dalam membaca } \\
\text { permulaan yaitu kurangnya minat belajar Pembelajaran yang } \\
\text { dilakukan sesekali oleh Windri di rumah yaitu membaca huruf, } \\
\text { membaca suku kata, membaca kata dan menirukan sang ayah. }\end{array}$ \\
\hline
\end{tabular}




\begin{tabular}{|c|c|c|}
\hline 4. & Novila Putri Gusmi & $\begin{array}{l}\text { Novila Putri Gusmi berjenis kelamin perempuan, berumur } 7 \text { tahun. } \\
\text { Novila Putri Gusmi pernah bersekolah di Taman Kanak-Kanak, ia } \\
\text { sudah mengenal huruf A-Z. Kesulitan yang dihadapi Novila Putri } \\
\text { Gusmi dalam membaca permulaan yaitu belum bisa membaca suku } \\
\text { kata, belum bisa membaca kata dan belum bisa membaca kata yang } \\
\text { tidak mempunyai arti. Wawancara yang dilakukan terhadap Novila } \\
\text { Putri Gusmi menghasilkan deskripsi tentang faktor penghambat } \\
\text { dalam membaca permulaan yaitu kurangnya minat belajar. } \\
\text { Pembelajaran yang dilakukan sesekali oleh Novila Putri Gusmi di } \\
\text { rumah yaitu membaca huruf, membaca suku kata, membaca kata dan } \\
\text { menirukan sang Ibu. }\end{array}$ \\
\hline 5. & Nabil Saputra & $\begin{array}{l}\text { Nabil Saputra berumur } 6 \text { tahun, berjenis kelamin laki-laki. Nabil } \\
\text { Saputra pernah bersekolah di Taman Kanak-Kanak (TK), kesulitan } \\
\text { yang dihadapi Nabil Saputra dalam membaca permulaan } \\
\text { diantaranya, belum mampu mengenal huruf A-Z, belum bisa } \\
\text { membaca suku kata, belum mampu membaca huruf diftong, belum } \\
\text { mampu mengenal huruf vokal, belum bisa membaca kata dan belum } \\
\text { bisa membaca kata yang tidak mempunyai arti. Wawancara yang } \\
\text { dilakukan terhadap Nabil Saputra menghasilkan deskripsi tentang } \\
\text { faktor penghambat kesulitan membaca permulaan yakni kurangnya } \\
\text { minat belajar membaca permulaan. Pembelajaran yang dilakukan } \\
\text { Nabil Saputra di rumah yaitu, membaca huruf, membaca suku kata, } \\
\text { membaca kata yang diajarkan dan dibacakan oleh ibunya. }\end{array}$ \\
\hline 6. & Dion Syaputra & $\begin{array}{l}\text { Dion Syaputra berumur } 7 \text { tahun, berjenis kelamin laki-laki. Dion } \\
\text { Syaputra pernah bersekolah di Taman Kanak-Kanak (TK). Kesulitan } \\
\text { yang dihadapi Dion Syaputra dalam membaca permulaan yaitu } \\
\text { belum mampu mengenal huruf A-Z, membaca suku kata, belum bisa } \\
\text { membaca kata dan belum bisa membaca kata yang tidak mempunyai } \\
\text { arti. Wawancara yang dilakukan terhadap Dion Syaputra } \\
\text { menghasilkan deskripsi tentang faktor penghambat kesulitan } \\
\text { membaca permulaan yakni kurangnya minat belajar Dion Syaputra. } \\
\text { Pembelajaran yang dilakukan Dion Syaputra di rumah yaitu, } \\
\text { membaca huruf, membaca suku kata, membaca kata yang dibacakan } \\
\text { dan diajarkan oleh kakaknya. }\end{array}$ \\
\hline 7. & Kevin Mariengga & $\begin{array}{l}\text { Kevin Mariengga berumur } 7 \text { tahun, berjenis kelamin laki-laki. Kevin } \\
\text { Mariengga pernah bersekolah di Taman Kanak-Kanak (TK), Kevin } \\
\text { Mariengga sudah mampu mengenal huruf A-Z. Kesulitan yang } \\
\text { dialami Kevin Mariengga dalam membaca permulaan yaitu, belum } \\
\text { bisa membaca suku kata, belum bisa membaca kata, belum bisa } \\
\text { membaca kata yang tidak mempunyai arti, dan tidak suka membaca. }\end{array}$ \\
\hline
\end{tabular}




\begin{tabular}{|c|c|c|}
\hline & & $\begin{array}{l}\text { Wawancara yang dilakukan terhadap Kevin Mariengga } \\
\text { menghasilkan deskripsi tentang faktor penghambat dalam membaca } \\
\text { permulaan yaitu kurangnya minat belajar. Pembelajaran yang } \\
\text { dilakukan Kevin Mariengga di rumah yaitu, membaca huruf, } \\
\text { membaca suku kata, membaca kata yang diajarkan dan dibacakan } \\
\text { oleh kakaknya. }\end{array}$ \\
\hline 8. & Muhammad Razib & $\begin{array}{l}\text { Muhammad Razib berjenis kelamin laki-laki, berumur } 8 \text { tahun. } \\
\text { Muhammad Razib pernah bersekolah di Taman Kanak-Kanak. } \\
\text { Kesulitan membaca permulaan yang dialami Muhammad Razib } \\
\text { yaitu, belum menghafal huruf A-Z, belum bisa membaca suku kata, } \\
\text { belum bisa membaca kata dan belum bisa membaca kata yang tidak } \\
\text { mempunyai arti. Wawancara yang dilakukan terhadap Muhammad } \\
\text { Razib menghasilkan deskripsi tentang faktor penghambat } \\
\text { Muhammad Razib dalam membaca yaitu kurangnya minat belajar. } \\
\text { Pembelajaran yang dilakukan sesekali oleh Dava di rumah yaitu } \\
\text { membaca huruf, membaca suku kata, membaca kata dan menirukan } \\
\text { sang Ibu. }\end{array}$ \\
\hline 9. & Pandu Fahrul Lazi & $\begin{array}{l}\text { Pandu Fahrul Lazi berjenis kelamin laki-laki, berumur } 7 \text { tahun. } \\
\text { Pandu Fahrul Lazi pernah bersekolah di Taman Kanak-Kanak, ia } \\
\text { sudah mengenal huruf A-Z. Kesulitan yang dialami Pandu Fahrul } \\
\text { Lazi dalam membaca permulaan yaitu, belum bisa membaca suku } \\
\text { kata, belum bisa membaca kata dan belum bisa membaca kata yang } \\
\text { tidak mempunyai arti. Wawancara yang dilakukan terhadap Pandu } \\
\text { Fahrul Lazi menghasilkan deskripsi tentang faktor penghambat } \\
\text { dalam membaca permulaan yaitu kurangnya minat belajar. } \\
\text { Pembelajaran yang dilakukan sesekali oleh Pandu Fahrul Lazi di } \\
\text { rumah yaitu membaca huruf, membaca suku kata, membaca kata dan } \\
\text { menirukan kedua orangtuanya. }\end{array}$ \\
\hline 10. & $\begin{array}{l}\text { Habib } \\
\text { Mahendra }\end{array}$ & $\begin{array}{l}\text { Habib Naufal Mahendra berjenis kelamin laki-laki, berumur } \\
7 \text { tahun. Habib Naufal Mahendra tidak pernah bersekolah di Taman } \\
\text { Kanak-Kanak sehingga belum mengenal huruf A-Z. Kesuitan lain } \\
\text { yang dihadapi Habib Naufal Mahendra dalam membaca permulaan } \\
\text { yaitu belum bisa membaca suku kata, ia belum bisa membaca kata } \\
\text { dan belum bisa membaca kata yang tidak mempunyai arti. } \\
\text { Wawancara yang dilakukan terhadap Habib Naufal Mahendra } \\
\text { menghasilkan deskripsi tentang faktor penghambat dalam membaca } \\
\text { permulaan yaitu kurangnya minat belajar. Pembelajaran yang } \\
\text { dilakukan sesekali oleh Habib Naufal Mahendra di rumah yaitu } \\
\text { membaca huruf, membaca suku kata, membaca kata dan menirukan } \\
\text { sang Ibu. }\end{array}$ \\
\hline
\end{tabular}


Berdasarkan hasil wawancara dengan guru kelas I SDN 002 Pulau Baru Kopah membaca permulaan pada siswa kelas 1 dapat dikatakan "belum baik" karena dari 21 siswa ada 10 siswa yang belum lancar dan belum bisa membaca permulaan. Hal ini dapat dilihat ketika kegiatan belajar mengajar berlangsung, hampir dari separuh siswa kelas I belum lancar dalam membaca permulaan. Faktor-faktor yang menghambat siswa dalam membaca permulaan yaitu siswa malas belajar, siswa susah berkonsentrasi saat belajar, beberapa siswa tidak pernah mendapatkan pendidikan taman kanakkanak, dan kurangnya perhatian orang tua dalam mengajarkan membaca pada anak. Solusi yang diberikan guru untuk mengatasi kesulitan-kesulitan membaca permulaan siswa kelas I SDN 002 Pulau Baru Kopah adalah mewajibkan membawa buku bacaan dan mengadakan les baca setelah KBM selesai bagi siswa yang belum bisa membaca. Metode lain yang diterapkan dalam pembelajaran membaca permulaan di kelas I SD yaitu dengan metode mengeja, mengenalkan huruf, dan mengenalkan suku kata dengan bantuan buku bacaan siswa.

Setelah peneliti melakukan observasi dan wawancara kepada guru kelas I, siswa kelas I, dan hasil dokumentasi, maka diperoleh data tentang kesulitan-kesulitan membaca permulaan pada siswa kelas SDN 022 Pulau Baru Kopah. Berdasarkan hasil analisis terhadap 21 siswa diperoleh data 10 siswa menghadapi kesulitan membaca permulaan. Berdasarkan hasil tersebut dapat diketahui bahwa tingkat membaca permulaan pada siswa kelas I SDN 002 Pulau Baru Kopah tergolong "Belum Baik”. Kesulitan-kesulitan yang dihadapi oleh siswa kelas 1 SDN 002 Pulau Baru Kopah sebagai berikut.

\section{a. Belum mengenal huruf}

Ketidakmampuan siswa kelas 1 SDN 002 Pulau Baru Kopah dalam mengenal huruf-huruf alfabetis menjadi salah satu faktor penghambat siswa tidak mampu membaca. Berdasarkan hasil wawancara dan observasi yang telah dilakukan kepada guru dan siswa, dapat diketahui bahwa siswa yang belum mengenal huruf adalah mereka yang tidak pernah mendapatkan pendidikan di TK (Taman Kanak-kanak).

b. Belum mampu membaca suku kata

Suku kata merupakan pemenggalan kata berdasarkan ucapan. Beberapa siswa kelas 1 SDN 002 Pulau Baru Kopah menghadapi kesulitan membaca suku kata. Suku kata yang tidak bisa dilafalkan berupa suku kata terbuka maupun suku kata tertutup. Suku kata terbuka adalah suku kata yang diakhiri dengan huruf vokal contoh: $m i, l a, g a$, dsb. Suku kata tertutup adalah suku kata yang diakhiri dengan huruf konsonan contoh: kan, bal, dang, dsb. Pada tahap ini, siswa sudah mengenal huruf-huruf alfabetis, namun siswa belum mampu membentuk satu pengucapan kata. Beberapa siswa kelas 1 SDN 002 Pulau Baru Kopah tersebut membutuhkan latihan rutin untuk mempercepat keterampilan membaca. 
c. Membaca kata demi kata

Kesulitan membaca kata demi kata juga dialami oleh siswa kelas 1 SDN 002 Pulau Baru Kopah. Siswa berhenti membaca setelah membaca sebuah kata. Siswa tidak mampu membaca kata berikutnya. Hal ini biasanya disebabkan karena gagal menguasai keterampilan pemecahan kode (decoding), gagal memahami makna kata, dan kurang lancar membaca. Kegiatan membaca secara teratur dapat membantu siswa lebih lancar dalam membaca kata demi kata. Kegiatan membaca berkaitan dengan pengenalan huruf atau rangkaian kata, makna atau maksud, dan pemahaman terhadap makna atau maksud, sehingga kegiatan membaca tidak dilakukan secara teratur maka keterampilan membaca yang dimiliki anak akan berkurang dengan sendirinya.

d. Belum mampu membaca huruf diftong, kluster, dan digraf

Dalam bahasa Indonesia dapat dijumpai adanya diftong (gabungan dua vokal). Hal tersebut merupakan salah satu sumber kesulitan siswa kelas 1 SDN 002 Pulau Baru Kopah yang sedang belajar membaca. Selain diftong, siswa kelas 1 SDN 002 Pulau Baru Kopah juga kesulitan membaca huruf kluster dan digraf. Kluster yaitu (gabungan dua konsonan atau lebih) sedangkan digraf adalah (dua huruf yang melambangkan satu bunyi).

e. Belum mampu membaca huruf konsonan

Beberapa siswa kelas 1 SDN 002 Pulau Baru Kopah belum mampu membaca huruf konsonan. Kesulitan dalam mengucapkan bunyi konsonan ini disertai dengan kesulitan mengucapkan huruf yang melambangkan konsonan tersebut.

f. Belum mampu membaca huruf vokal

Siswa kelas 1 SDN 002 Pulau Baru Kopah belum mampu membedakan beberapa vokal yang dilambangkan dalam satu huruf. Contoh dari beberapa vokal yang dilambangakan dalam satu huruf yaitu /e/ yang selain melambangkan bunyi e juga melambangkan bunyi é (dalam kata keras, kepala, kerang, telah, dan sebagainya). Huruf-huruf yang melambangkan beberapa bunyi seringkali menjadi sumber kesulitan siswa dalam membaca.

g. Pengulangan

Beberapa siswa kelas 1 SDN 002 Pulau Baru Kopah memiliki kebiasaan mengulangi kata atau frasa dalam membaca. Kebiasaan siswa mengulangi kata atau frasa dalam membaca disebaban oleh faktor tidak mengenali kata, kurang menguasai huruf, bunyi, atau rendah keterampilannya.

h. Memprafase yang salah

Beberapa siswa kelas 1 SDN 002 Pulau Baru Kopah sering melakukan pemenggalan (berhenti membaca) pada tempat yang tidak tepat atau tidak memperhatikan tanda baca, khususnya tanda koma. 
i. Belum mengenali makna kata

Beberapa Siswa kelas 1 SDN 002 Pulau Baru Kopah kesulitan mengenali makna kata, hal tersebut disebabkan kurangnya penguasaan kosakata, kurangnya penguasaan struktur kata, dan penguasaan unsur konteks (kalimat dan hubungan antar kalimat).

Berdasarakan pemaparan tersebut, dapat diambil kesimpulan bahwa kesulitan membaca permulaan yang dialami siswa kelas I SDN 002 Pulau Baru Kopah sangat majemuk. Mulai dari siswa tidak mengenal huruf, siswa tidak mengenal huruf vokal, siswa tidak mengenal huruf konsonan, siswa tidak mengenal huruf diftong, siswa tidak bisa membaca suku kata, siswa tidak bisa membaca kata, dan lain sebagainya.

Beberapa solusi diberikan guru untuk mengatasi kesulitan membaca permulaan siswa kelas 1 di SDN 002 Pulau Baru Kopah, diantaranya sebagai berikut.

a. Guru mengadakan jam tambahan bagi siswa yang masih kesulitan membaca permulaan.

Solusi pertama yang diberikan guru adalah dengan memberikan jam tambahan kepada siswa yang mengalami kesulitan membaca permulaan. Seperti pada saat peneliti melakukan observasi di kelas IA tanggal 19 Juli 2021. Pada jam istirahat, guru meminta siswa yang mengalami kesulitan membaca untuk tetap diam di dalam kelas. Siswa diajarkan untuk mengenal huruf dari A-Z dan melafalkan di depan guru. Siswa yang sudah dapat melafalkan dengan benar akan diberikan izin untuk istirahat.

b. Guru memberikan perhatian lebih dan khusus untuk siswa yang tidak bisa membaca permulaan.

Solusi kedua yang diberikan guru untuk mengatasi kesulitan membaca permulaan siswa kelas $1 \mathrm{~A}$ adalah dengan memberikan perhatian lebih kepada siswa yang mengalami kesulitan dalam membaca permulaan. Berdasarkan hasil observasi peneliti dikelas IA, peneliti melihat bahwa guru memberikan perhatian lebih kepada siswa yang mengalami kesulitan dalam membaca permulaan. Perhatian yang diberikan guru adalah seperti pada saat proses pembelajaran, terdapat siswa yang salah dalam menuliskan huruf, maka guru akan membimbing siswa untuk menuliskan huruf dengan benar dan meminta melafalkan huruf tersebut agar siswa dapat mengingat huruf dan membedakan dengan huruf yang hampir sama seperti huruf $\mathrm{F}$ dan huruf V.

c. Bagi siswa yang mengalami kesulitan kurang mengenali huruf, guru memberikan solusi sebagai berikut.

1. Huruf dijadikan bahan nyanyian.

2. Menampilkan huruf dan mendiskusikan bentuk (karakteristiknya) khususnya huruf-huruf yang memiliki kemiripan bentuk (misalnya $\mathrm{p}, \mathrm{b}$, dan d). 
3. Menggunakan bacaan yang tingkat kesulitannya rendah.

4. Siswa diminta menulis kalimat dan membacanya dengan keras.

Berdasarkan hasil penelitian di atas, dapat ditarik kesimpulan bahwa untuk mengatasi kesulitan membaca permulaan siswa kelas 1 di Sekolah Dasar Negeri 002 Pulau Baru Kopah, solusi yang diberikan guru yaitu, memberikan jam tambahan kepada siswa yang mengalami kesulitan membaca permulaan, memberikan perhatian lebih kepada siswa yang mengalami kesulitan membaca, dan guru mengajarkan siswa mengenal huruf dengan gaya mengajar yang lebih kreatif.

Membaca pada dasarnya suatu kegiatan yang umum dilakukan manusia dalam rangka untuk mendapatkan informasi yang terkandung dalam sebuah tulisan. Membaca diartikan sebagai proses komunikasi yang dilakukan secara tidak langsung dari sumber pesan kepada penerima pesan dengan perantara media tulis (Pratiwi \& Ariawan, 2017). Kegiatan membaca sangat penting dilakukan dan dibiasakan guna untuk mendapatkan banyak informasi dan menambah wawasan yang dimiliki seseorang. Oleh karena itu untuk dapat membaca dengan baik diperlukan kemampuan dan keterampilan membaca yang telah dibelajarkan kepada anak mulai jenjang sekolah dasar. Namun demikian perlu diketahuai bahwa kegiatan pembelajaran membaca pada anak tidak semudah yang diperkirakan. Siswa yang menerima materi belajar membaca yang sama dan disampaikan oleh guru yang sama, namun progres kemampuan membaca mereka berbeda. Dalam satu kelas, di antara mereka ada yang sudah mampu pandai membaca dengan cepat, akan tetapi ada juga yang masih kesulitan, bahkan ada yang masih mengalami hambatan merangkai huruf satu untuk membentuk sebuah kata. Kesulitan belajar membaca disebut juga disleksia (dyslexia) yang berasal dari bahasa Yunani yang artinya kesulitan membaca.

Disleksia sebagai suatu sindrom kesulitan dalam mempelajari komponen-komponen kata dan kalimat dalam belajar, segala sesuatu yang berkenaan dengan waktu, arah, dan masa (Kusuma Wardani, 2020). Sementara itu menurut Hornsby mendefinisikan disleksia tidak hanya kesulitan belajar membaca tetapi juga menulis.

Berdasarkan hasi penelitian di kelas IA SDN 002 Pulau Baru Kopah, terdapat kesulitankesulitan yang dialami siswa mengenai membaca permulaan. Kesulitan yang dialami siswa yaitu siswa tidak mengenal huruf, siswa tidak mengenal huruf vokal, siswa tidak mengenal huruf konsonan, siswa tidak mengenal huruf diftong, siswa tidak bisa membaca suku kata, siswa tidak bisa membaca kata, pengulangan, dan yang terakhir adalah siswa belum mengenali makna kata.

Hal tersebut sesuai dengan hasil penelitian menurut (Pridasari \& Anafiah, 2020) yang menyatakan bahwa kesulitan-kesulitan membaca permulaan siswa adalah (1) belum mampu membaca diftong, vokal rangkap, dan konsonan rangkap, (2) belum mampu membaca kalimat, (3) 
membaca tersendat-sendat, (4) belum mampu menyebutkan beberapa huruf konsonan, (5) belum bisa mengeja, (6) membaca asal-asalan, (7) cepat lupa kata yang telah diejanya, (8) melakukan penambahan dan penggantian kata, (9) waktu mengeja cukup lama, dan, (10) belum mampu membaca dengan tuntas.

Untuk mengatasi kesulitan-kesulitan yang dialami siswa terkait membaca permulaan, guru memberikan solusi yang diharapkan mampu mengatasi kesulitan siswa tersebut. Beberapa solusi diberikan guru untuk kesulitan membaca permulaan yang dialami siswa kelas IA SDN 002 Pulau Baru Kopah. Pertama, guru memberikan jam tambahan kepada siswa yang memiliki kesulitan dalam membaca permulaan. Kedua, memberikan perhatian lebih kepada siswa yang mengalami kesulitan membaca permulaan. Ketiga, guru membantu siswa untuk dapat mengenal huruf dengan baik dengan cara menjadikan huruf sebagai bahan nyanyian, menampilkan huruf dan mendiskusikan bentuk (karakteristiknya) khususnya huruf-huruf yang memiliki kemiripan bentuk (misalnya p, b, dan d), menggunakan bacaan yang tingkat kesulitannya rendah dan siswa diminta menulis kalimat dan membacanya dengan keras.

Hal tersebut hampir sesuai dengan menurut (Udhiyanasari, 2019) bahwa solusi atau upaya yang dapat diakukan guru untuk mengatasi kesulitan membaca permulaan siswa diantaranya sebagai berikut.

a. Menggunakan media pembelajaran yang menarik dan efektif, menggunakan metode pembelajaran dengan bantuan gambar akan sangat memudahkan siswa dalam mengenal huruf.

b. Membacakan dongeng dan menjelaskan berbagai macam manfaat dengan biasa membaca dapat mendorong rasa percaya disi siswa. Selain itu percaya diri juga harus ditimbulkan karena siswa yang mengalami kesulitan membaca sulit dalam mengikuti pelajaran di kelas, sehingga sering dikucilkan oleh teman sekelasnya. Hal tersebut juga dapat dilakukan dengan menimbulkan rasa percaya diri siswa dengan cara memunculkan semangat belajar anak di kelas.

c. Memberikan program khusus membaca remedial. Program tersebut mengacu pada pemberian remedial kepada anak yang mengalami kesulitan membaca.

d. Memberikan perhatian lebih kepada siswa yang mengalami kesulitan membaca.

\section{KESIMPULAN}

Bedasarkan hasil penelitian yang dilakukan di SDN 002 Pulau Baru Kopah, dapat ditarik kesimpulan bahwa keterampilan membaca permulaan siswa kelas 1A dapat dikatakan "Belum baik". Hal ini dikarenakan masih banyak siswa yang memiliki kesulitan membaca permulaan. Persentase 
siswa yang mengalami kesulitan membaca permulaan adalah 47,6\%. Kesulitan-kesulitan siswa dalam membaca permualan di kelas I SDN 002 Pulau Baru Kopah diantaranya siswa belum mengenal huruf, siswa belum bisa membaca suku kata, membaca kata demi kata, belum bisa membaca huruf diftong, kluster, diagraf, belum mampu membaca huruf konsonan, belum mampu membaca huruf vokal, pengulangan, pemprafase yang salah, dan belum mengenali makna kata.

Solusi yang diterapkan guru untuk mengatasi permasalahan siswa dalam kesulitan membaca permulaan di kelas I SDN 002 Pulau Baru Kopa, yaitu guru mengadakan jam tambahan bagi siswa yang masih kesulitan membaca permulaan, Guru memberikan perhatian lebih dan khusus untuk siswa yang masih tidak bisa membaca permulaan, guru mengajari siswa mengenal huruf dengan beberapa Teknik, misalnya huruf dijadikan bahan nyanyian, menampilkan huruf dan mendiskusikan bentuk (karakteristiknya) khususnya huruf-huruf yang memiliki kemiripan bentuk (misalnya p, b, dan d ), menggunakan bacaan yang tingkat kesulitannya rendah, serta siswa diminta menulis kalimat dan membacanya dengan keras.

\section{DAFTAR PUSTAKA}

Dafit, F., \& Ramadan, Z. H. (2020). Pelaksanaan Program Gerakan Literasi Sekolah (GLS) di Sekolah Dasar. Jurnal Basicedu, 4(4), 1429-1437. https://doi.org/10.31004/basicedu.v4i4.585

Kusuma Wardani, I. (2020). Prosiding Konferensi Ilmiah Dasar Analisis kesulitan membaca permulaan siswa kelas rendah. 2, 286-289. http://prosiding.unipma.ac.id/index.php/KID

Mabunga, A. S., Mabunga, M. E. M., \& Yani, A. (2019). Kesulitan Membaca Permulaan Pada Anak Usia Dini Dalam Perspektif Analisis Reading Readiness. Mimbar Pendidikan, 4(2), 113-126. https://doi.org/10.17509/mimbardik.v4i2.22202

Masykuri. (2017). Analisis Kesulitan Membaca Permulaan pada Siswa Kelas I MI Pesantren Pembangunan Cibeunying Kecamatan Majenang Kabupaten Cilacap Tahun 2017/2018. 120.

Muhyidin, A., Rosidin, O., \& Salpariansi, E. (2018). Metode Pembelajaran Membaca Dan Menulis Permulaan Di Kelas Awal. Jurnal Pendidikan Sekolah Dasar, 4(1), 30. https://doi.org/10.30870/jpsd.v4i1.2464

Pratiwi, I. M., \& Ariawan, V. A. N. (2017). Analisis Kesulitan Siswa Dalam Membaca Permulaan Di Kelas Satu Sekolah Dasar. Sekolah Dasar: Kajian Teori Dan Praktik Pendidikan, 26(1), 6976. https://doi.org/10.17977/um009v26i12017p069

Pridasari, F., \& Anafiah, S. (2020). Analisis Kesulitan Membaca Permulaan Pada Siswa Kelas I Di Sdn Demangan Yogyakarta. TRIHAYU: Jurnal Pendidikan Ke-SD-An, 6(2), 432-439. 
https://doi.org/10.30738/trihayu.v6i2.8054

Purba, J. P. (2012). Pemecahan Masalah dan Penggunaan Strategi Pemecahan Masalah. Artikel P.J.Purba, 1-8.

Rafika, N., \& Lestari, K. M. \& S. (2020). Analisis kesulitan membaca permulaan pada siswa sekolah dasar. Prosidig Konferensi Ilmiah Dasar, 2, 301-306.

Udhiyanasari, K. Y. (2019). Upaya Penanganan Kesulitan Membaca Permulaan Pada Anak Berkesulitan Membaca Kelas II di SDN Manahan Surakarta. Plpb Ikip Pgri Jember, 3(1), 3950. 